\title{
Effect of Workload on Employee Performance through Work Life Balance at Ollino Garden Hotel Malang East Java
}

\author{
Syihabudhin Syihabudhin*, Elfia Nora, Lohana Juariyah, Afwan Hariri, Ofan Dhika \\ Universitas Negeri Malang \\ Malang, Indonesia \\ *syihabudhin.fe@um.ac.id
}

\begin{abstract}
The problem that often arises in Ollino Garden Hotel Malang is high workload due high season. Therefore, this study was conducted, where the purpose of this study was to find out. 1) the description of workload, work life balance and job performance at Ollino Garden Hotel Malang; 2) whether workload effect and significantly towards the work life balance at Ollino Garden Hotel Malang; 3) whether work life balance effect and significantly towards the job performance in Ollino Garden Hotel Malang; 4) whether workload effect and significantly towards the job performance at Ollino Garden Hotel Malang; 5) whether workload bears indirectly effect towards job performance through work life balance at Ollino Garden Hotel Malang. This study uses an instrument in the form of a questionnaires, the results of the data from the questionnaire will be analyzed using path analysis. The population used in this study were 48 employees of Ollino Garden Hotel Malang. Sampling technique used is Proportionate Random Sampling, resulting in a sample number of 43 employees of all employees Ollino Garden Hotel Malang. Based on the results of path analysis, it can be seen that: 1) Workload, work life balance and employee performance at Ollino Garden Hotel Malang are categorized as good; 2) Workload has a positive and significant effect on work life balance; 3 ) Work life balance has a positive and significant effect on performance; 4 ) workload has a negative and significant effect on performance; 5) Indirect workload has a positive effect on performance through work life balance at Ollino Garden Hotel Malang.
\end{abstract}

Keywords—workload, work life balance, employee performance

\section{INTRODUCTION}

Workload is the burden owned by employees in doing work that is their responsibility and how they can manage tasks to meet the demands of the operating system, in his work. The resource physic is very dic with the mental demands that affect human performance as well as the processing of information [1].

Rahayu delivers the workload category (two) i.e. quantitative workloads and qualitative workloads [2]. Quantitative workloads show a greater amount of work to do, such as high enough work hours and considerable working pressure. Qualitative workloads are related to the ability for workers to carry out their work. High workloads will have an effect on good or poor employee-generated performance. This is evidenced by the research conducted by Paramita Dewi which shows that if the workload is charged to the low employee then the employee's performance will increase, likewise otherwise if the workload is perceived Employee's performance will decrease [3]. But the results of the study are not entirely true, as some research proves that the workload has no significant effect on performance, even workloads do not have a significant impact on performance.

When employees feel their overwork, it can pose a problem in the employee's personal life that leads to low performance. One of the problems arising from workload is the employee's work life balance, where overwork can lead to a decline in work life balance. But the excess workload can be a positive thing for the work life balance, where the excess workload is considered a challenge and a boost by a person. When the workload is considered a boost because employees ' ability to deal with its workload, it will satisfy the desire in employees so that their work life balance will be fulfilled.

According to Parkes and Langford, work life balance is a person's ability to balance work and personal life, fulfilling commitments, can be held accountable to other activities outside of their work [4]. Work life balance is closely related to the balance between effort and amount of time focused on work and personal life. It is important for companies to support employees in achieving a work life balance. This is a work life balance that is a major topic in working. According to Kim in Levi \& Asima, work-life balance has a significant important role with the psychological welfare, which is defined the extent to which an individual has a purpose in his life, whether they realize the potential [5]. The quality of its relationship with When employees feel their high workload, it can pose a problem in the employee's personal life that leads to low performance.

Ollino Garden Hotel Malang, a 3-star Hotel that has 83 rooms, as well as 3 halls is located in the very strategic heart of Malang, because this Hotel is close to the center of Malang City and new tourist attractions, such as Kampung Warna Warni Jodipan (KWJ), Kampung and Arema Blue Village. Not only that, the Hotel which is located adjacent to Arema Blue village has a Roman feel in every building design, making an attraction of its own to the consumer plus the view of this Hotel overlooks the Brantas River which is now Become a new tour of Malang City. However, there are some problems faced by Ollino Garden Hotel Malang with regards to human resources. The Ollino Hotel, which was established in 2005, has experienced the increasing number of tourists and event 
requests, will also improve the workload of every employee. Ollino Garden Hotel which has 48 employees, has a high workload, because the results obtained by researchers from the interview average percentage occupancy when the high season rises by 90 percent from 83 rooms each month. While the average for an existing event rises by 80 percent each month. The hotel also has limited human resources, because many employees are moved to different hotels that are no other subsidiary of Ollino Garden Hotel Malang.

Ollino Garden Hotel Employees when overtime always get extra money, but cannot be denied the employees of Ollino Garden Hotel often miss the moment to gather with family, hobbies and life. Many employees spend time for his job and left time outside his work. It is coupled with not having employees change the working hours the next day after a day of busy activities, it is explained by HRD Ollino Garden Hotel Malang. But the company provides health benefits, and gives employees the freedom to plan work hours for the following week with the approval of the lead to assist employees in work life balance. According to Kim in Levi \& Asima that work-life balance has an important role in the psychological welfare [5]. When the psychological welfare of employees is fulfilled, it will have good impact on its performance.

While the performance in the hotel according to interviews, employees will maximize the ability to complete the task even in high season. But it can't be denied when high season according to some other employees sometimes they feel its performance at Ollino Garden Hotel is less than maximal. Therefore, researchers want to know the real state of employee performance during high season. Because when the work is conducted when the low season workload has also matched the portion, the performance will be good. Performance at Ollino Garden Hotel is not only assessed by completion of the task, but there are some points that are indicators of performance assessment at Ollino Garden Hotel. The purpose of this research is: 1) How is the description of workload, work life balance, and performance in Ollino Garden Hotel Malang, 2) is there a significant impact on the work life balance at Ollino Garden Hotel Malang, 3) is there any influence Significant work life balance against performance in Ollino Garden Hotel Malang, 4) is there any significant effect on the workload performance in Ollino Garden Hotel unfortunate, 5) is there any impact on performance workload through work life balance in Ollino Garden Hotel Malang.

\section{Methods}

The hypotheses of the research 1) whether workload effect and significantly towards the work life balance at Ollino Garden Hotel Malang; 2) whether work life balance effect and significantly towards the job performance in Ollino Garden Hotel Malang; 3) whether workload effect and significantly towards the job performance at Ollino Garden Hotel Malang; 4) whether workload bears indirectly effect towards job performance through work life balance at Ollino Garden Hotel Malang. The types of research conducted are methods of descriptive and explanatory research.

A descriptive method is a method used to describe in detail about the variable. While the explanatory research method or research explanation where the research explains the relationship between the variables to be researched.
This research is expected to describe the relationship of workload variables (X), Work life balance (Z) and Performance (Y). In figure 1, the design of this study, the analysis used on the path model is the path analysis, where the technique will test the hypothesis that states there is an influence between workload $(\mathrm{X})$ on employee performance (Y) through Work Life Balance $(\mathrm{Z})$.

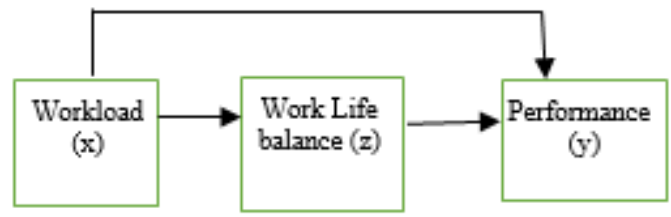

Fig. 1. The relationship between variables.

The population of this research is the employee Ollino Garden Hotel Malang is as much as 48 people. In this study using Proportional Random sampling techniques, because the samples on the objects will be divided into each existing division. This sampling technique is used as it can represent population in each division, samples obtained as much as 43 people.

\section{RESULTS}

Statistical analysis of descriptive workload Ollino Garden Hotel Malang The workload is measured by an indicator developed by Rahayu where the indicator has 3 conditions of employment, the use of working time as well as targets must be achieved [2]. As well as in this case researchers use the 7 scale interval measurement. The Grand Mean workload gets an average value of 4.33 . That is included in the interval scale quite. Can be interpreted perceptual perception of employees in Ollino Garden is quite excessive.

\section{A. Work Life Balance Employees Ollino Garden Hotel Malang}

Work Life Balance is measured by an indicator developed by Hudson in Umartiwi, in which the indicator is a 3-time balance, engagement balance and balance satisfaction [6]. As well as in this case researchers use the 7 scale interval measurement. Work Life Balance with an average value of 5.77. From the average result that 43 respondents mostly answered very well balanced on the work life balance variable, this means that the employee's ability to perform work life balance is very balanced.

\section{B. Performance of Employees Ollino Garden Hotel Malang}

Performance is measured by the combined indicators developed by Prawirosentono, Gomes and Robbins where the indicator is 7 namely quantity, timeliness, effectiveness, discipline, corporation, initiative and personal quality. As well as in this case researchers use the 7 scale interval measurement. Ollino Garden Hotel Malang employee performance in variable performance by getting an average value of 5.49. From the average result that 43 respondents mostly answered very much to the performance variables, this meant that they had the view that the performance had been excellent. 


\section{Path Analysis Effect of Work Life Balance Workload}

TABLE I. RELATIONSHIP OF WORKLOAD TO THE WORK LIFE BALANCE

\begin{tabular}{|l|l|l|}
\hline \multirow{2}{*}{ Model } & $\begin{array}{c}\text { Standardized } \\
\text { coefficients }\end{array}$ & \multirow{2}{*}{ Sig. } \\
\cline { 2 - 3 } & \multicolumn{1}{|c|}{ Beta } & \\
\hline Work Load &, 387 &, 010 \\
\hline R. Square &, 150 & \\
\hline \multicolumn{2}{|l|}{ Dependend variabel : Work Life Balance } \\
\hline
\end{tabular}

According to the table 1 above, it can be seen that the relationship of workload to the Work Life Balance of Hotel Ollino Garden employees has a positive beta coefficient of 0.387 that has been standardized. From the table above can be seen the significance variable value of the workload $0.010<$ 0.05. Thus the hypothesis that States workloads are positive and significant to Work Life Balance is acceptable.

Based on the results the above regression equation can be concluded that the beta coefficient of variable workload can explain the work life balance variable by 0.387 . The next result of coefficient of determination or R Square amounted to 0.150 which means that the workload effect on the work life balance by $15 \%$. While the remaining $85 \%$ is influenced by other factors outside this regression model.

\section{Effects of Workload and Work Life Balance on Performance}

TABLE II. ANALYSIS OF WORKLOAD AND WORK LIFE BALANCE ON PERFORMANCE

\begin{tabular}{|l|l|l|}
\hline \multirow{2}{*}{ Model } & \multicolumn{1}{|c|}{$\begin{array}{c}\text { Standardized } \\
\text { coefficients }\end{array}$} & \multirow{2}{*}{ Sig. } \\
\cline { 2 - 3 } & \multicolumn{1}{|c|}{ Beta } & \\
\hline Workload &,- 399 &, 011 \\
\hline Work Life Balance &, 483 &, 002 \\
\hline R. Square &, 244 & \\
\hline Dependend variable : Performance \\
\hline
\end{tabular}

The results from the table 2 above table data analysis can be explained that the significance variable value of the workload $0.011<0.05$ and can be seen in the table the value of the negative beta is-0.399. Thus it can be interpreted hypothesized that the workload is negatively and significantly influential in performance acceptable. The next in the Work Life Balance variable shows the significance value of $0.002<0.05$ and a positive beta value of 0.483 so that the hypothesis stating that Work Life Balance is positive and significant to performance is also acceptable.

Based on the regression equation above results in data description, the following: Variable Beta coefficient workload can explain a performance variable of-0.399 variable beta coefficients the Work Life Balance can explain the performance variables of 0.483 results in the coefficient of $R$ Square determinations of 0.244 , then it can be interpreted That the impact of workload variables and the work life balance variables against performance amounted to $24.4 \%$. In other words, 75.6 the rest is influenced by other variables.

\section{E. Effect of Indirect Workload on Performance through Work Life Balance}

Analysis testing path to figure out indirect effect of workload on performance through work life balance, hence the following result is obtained

$$
\begin{aligned}
& \text { PTL }=\text { P_xz } \times \text { P_zy } \\
& \text { PTL }=0.387 \times 0.483 \\
& \text { PTL }=0.187
\end{aligned}
$$

Description:

PTL: Indirect impact

P_xz: effect of workload on Work Life Balance

P_zy: The effect of Work Life Balance on performance

Based on the above calculation, indirect influence can be known by 0.187 . This can be said that the work life balance is an intervening variable, where the workload affects indirect performance of work life balance.

Coefficient of determination Total results obtained from the model validity test using the total coefficient of determination method with the following values.

$R_{m}^{2}=1-P_{e_{1}}^{2} P_{e_{2}}^{2}$

$R_{m}^{2}=1-(0,922)^{2} \times(0,870)^{2}$

$R_{m}^{2}=1-(0,850) \times(0,757)$

$R_{m}^{2}=1-0,643$

$R_{m}^{2}=0,357$

The result of the calculation shows the diversity of data on the model is 0.357 in other words the information contained in the data of $35.7 \%$ which can be explained by the model. The remaining $64.3 \%$ can be explained by other variables.

Based on the tests that have been conducted by researchers there is the influence of workload on performance either directly or indirectly through work life balance. The following hypothesis testing can be described in the following table:

TABLE III. HYPOTHESIS TESTING

\begin{tabular}{|l|l|l|c|}
\hline \multicolumn{1}{|c|}{ Track Template } & \multicolumn{3}{|c|}{ Effect } \\
\cline { 2 - 5 } & \multicolumn{1}{|c|}{ Direct } & \multicolumn{1}{c|}{ Indirect } & 0,387 \\
\hline $\begin{array}{l}\text { Workload on work life } \\
\text { balance }\end{array}$ & 0,387 & - & $-0,212$ \\
\hline $\begin{array}{l}\text { Workload on } \\
\text { Performance }\end{array}$ & $-0,399$ & $\begin{array}{l}\text { work life balance }(0,387 \\
\text { x } 0,483)=0,187\end{array}$ & 0,483 \\
\hline $\begin{array}{l}\text { Work life balance on } \\
\text { Performance }\end{array}$ & 0,483 & - & \\
\hline
\end{tabular}

The table 3 above shows that the workload variable $(\mathrm{X})$ affects performance (Y) directly with the value of $\beta$ with the standard-0.399. The workload (X) affects performance (Y) indirectly with a value of $\beta$ with a standard of 0.187 with a total of-0.212 multiplier. Below are the images that describe the direct or indirect influences between variables. 


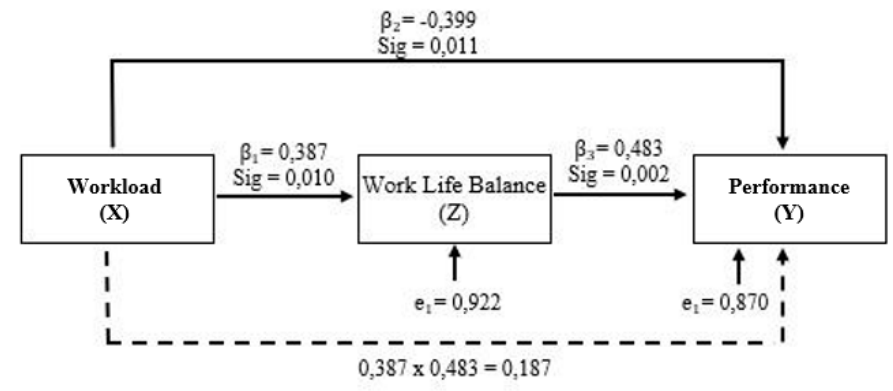

Fig. 2. Analysis results between variables.

Based on figure 2, the visible relationship between variables in this study, it can be concluded that the effect of workload on performance with the use of work life balance as an intervening variable has a total impact of-0.212. The use of work life balance as an intervening variable on the influence of performance workloads has also the value of $\mathrm{R}$ Square determinations of 0.357 which can mean that the model contains information of $35.7 \%$. The remaining $64.3 \%$ is explained by other variables outside the model.

In the results of this research there are variables that have a negative and significant direct influence, that is variable workload to performance. But when viewed from indirect influence through work life balance as an intervening variable, the workload has a positive and significant impact on performance.

\section{DisCUSSION}

\section{A. Workload Employees Ollino Garden Hotel Malang}

Perceptions of employee workload at Ollino Garden Hotel Malang have a considerable level of workload. The data obtained from the dissemination of questionnaires to 43 respondents contained about the perception of Ollino Garden Hotel Malang Employees regarding the workload, which is then collected and injected into the frequency distribution. So it can be known that the employee workload rate at Ollino Garden Hotel Malang has an average of enough and entered in a fairly excess category, it means that the employee workload rate is sufficient, not too high and not Too low.

In this research, the workload has 3 indicators, where the indicator has the highest value of the indicator of occupational conditions by entering the category of no excess, where the employee feels the condition of his work is in accordance with what is expected, so that the employee feels the condition of his work as expected. Whereas the indicator that has the lowest value is an indicator of the use of working time with sufficient/moderate category. Some employees feel even though their job conditions correspond to their skills, but on the other hand they still feel the time it takes to finish the job sometimes.

As for the target indicator that must be achieved in the category is enough, where this means that the employee feels the target that the company has given to them is sufficient, not excessive and not less. Based on the explanation above indeed the conception of employees about the workload in Ollino Garden can be fairly/moderate.

\section{B. Work Life Balance at Ollino Garden Hotel Malang}

Work Life Balance employees at Ollino Garden Hotel Malang have work life balance level. From the dissemination of the questionnaire to 43 respondents contained about the conception of work life balance that the employee felt at Ollino Garden Malang Hotel which then the data is collected and is being added to the frequency distribution. So it can be known that the work life balance level of employees at Ollino Garden Hotel Malang has an average value in the category is very good, it means that the employee's work life balance level is very balanced.

\section{Performance at Ollino Garden Hotel Malang}

The performance of employees at Ollino Garden Hotel Malang has excellent performance. From the propagation of the survey results to 43 respondents contained about the performance prevalence of employees performed at Ollino Garden Hotel Malang which then the data was collected and was added to the frequency distribution. So it can be known that the performance of employees at Ollino Garden Hotel Malang has a very good average and in the category of very agreed, it means that the employees ' performance at Ollino Garden Hotel Malang is very high.

The performance variable has 7 indicators, where all indicators are in the category very well. For indicators that have the highest average is discipline, whereas for indicators with the lowest average value is the initiative. Quantity indicator in category is very good, means employees there feel able to complete a task that has been determined by a certain amount and well and carefully. For the second indicator of timeliness, where the employee is able to carry out the job with the efficient and not procrastinating, and employees are able to carry out all their work with the time specified. The third indicator is effectiveness also included in the category is very good, this implies that the employees Ollino Garden Hotel Malang always do the work by using existing organizational resources without making it useless and employees can afford Doing more than one job at a time to perform the effectiveness of its work.

The fourth indicator, which is discipline has the highest average value of another indicator, it shows the discipline of the employee in orderly administration such as to comply with the company's rules, such as when shifting shifts of work, permits Out of the hotel and permits when attendance is strongly obeyed. The fundamental thing is also for every company that Ollino Garden Hotel Malang employees always come to work on time and it makes the rate of delay very low.

While the fifth indicator, namely Corporation also entered in the category is very good, where the employees Ollino Garden Hotel Malang able to communicate very well to employers and co-workers, so that the lack of disagreement and conflict Between parts. Employees can also resolve all existing issues with their co-workers. The sixth indicator is an indicator that has the lowest average value, but is also still in very good category. This shows that employees have a very high level of initiative, they always give an idea if you want to do the job without having to be ruled first.

What makes this indicator has the lowest average even though the category is very good is, maybe employees are limited by the company's operational standards (SOP), making them dare not to handle jobs outside their work, but they 
Always try to do the job without being notified first by the supervisor. This indicator is personal quality, which in every service company, this is the first judgment by the employer, of course in this case employees Ollino Garden Hotel Malang has an excellent personal quality indicator, because employees There felt that they had obeyed what the superiors ruled against him, able to maintain his attitude and appearance to the customer, able to provide ideas and always solve problems with colleagues in case of conflict without involving Anyone. Based on the explanation above is indeed a performance conception of employees at Ollino Garden Hotel Malang arguably very good.

\section{Effect of workload on Work Life Balance}

The results of the data analysis that researchers have conducted in the previous chapter, it can be noted that there is a positive and significant direct influence between workloads on work Life Balance in Ollino Garden Hotel Malang. Can be deduced increasingly workload is increasing the ability of employees in the work life balance at Ollino Garden Hotel Malang. This equally supported statement Robbins in Umartiwi states that workload pressure can be positive, with this leading to the satisfied work-life balance of employees [6]. If each employee has a positive workload, the employee will feel balanced between the demands of the work and the personal life of the employee. Employees who perceive the workload positively will understand the workload as a challenge rather than pressure, which will make themselves driven to achieve a good performance task. The results of this research are also supported by the research of Anisa, et al where the workload variables are positively and significantly positive with the work life balance [7]. The study supported the idea of Shah et al in Anisa that employees who had workloads would be more active and energetic [7]. Therefore, the workload can be a positive thing and leads to an increase in the work life balance level of the employee. The H1 in this study is acceptable as it corresponds to the theory and is supported by past research that has been conducted.

\section{E. The Effect of Work Life Balance on Performance}

Increasing employees ' work life balance capability is also increasing its performance at Ollino Garden Hotel Malang. The result of this research shows that when employees are able to improve their work life balance, they will be increasingly concentrated in doing their work, which will improve performance. Whereas when the employee's work life balance is interrupted, it affects bad employee performance. According to a few experts like Kim suggests that work life balance has a significant role with performance [5]. Meanwhile, according to Asthankar in Maya mentions that from an entrepreneur's point of view that the work life balance has an effect on the overall employee's performance [8]. It is supported by previous research by Maya, Alfian R., Asima and Nilawati, Johanim et al. and Faisal et al., which suggests that work life balance is positive and significant to the employee's performance $[5,8,9]$. From the study, concluded that employees are able to increase work life balance, it will increase the concentration in working that it has an impact on its performance. Thus it can be said that the work life Balance has an influence on performance. The $\mathrm{H} 2$ in this study is acceptable as it corresponds to the theory and is supported by previous research that has been conducted.

\section{F. The Effect of Workload on Performance}

The more workload and performance decreases the employees in Ollino Garden Hotel are unfortunate. It is supported by experts namely Lisnayetti in Paramitadewi stating that the relationship between the workload and performance of employees, where if the high workload will cause performance to decline, or can be explained that the higher the workload an employee receives will affect the performance of such employees as well as vice versa [3]. The supporting research is Paramitadewi which raises the workload negatively and significantly to the employee's performance [3]. The H3 in the study is acceptable as it corresponds to the theory and is supported by previous research that has been conducted.

\section{G. Effect of Workload on Performance through Work Life Balance}

The results of the research data analysis show that workload and work life balance become one of the factors that affect employees' performance at Ollino Garden Hotel Malang. The results of this research can be interpreted when the workload is high can have a positive effect on the performance because the workload is considered a challenge not suor obstacle, according to the expert statement that is Artadi reveals the workload Positive effect on employee performance where workload pressure can be positive, and this leads to improved performance. Early research also explains that workloads have a positive effect on performance through other variables, such as the research of Raunaqi that makes stress work a variable of intervening and Irawati, and friends which makes Intrinsic motivation as an intervening variable [10]. Plus, the research results by Denizia and Tri stating that the work life balance is able to be a mediation variable between the two other variables i.e. performance-heavy workloads [11]. The $\mathrm{H} 4$ in this study is acceptable as it corresponds to the theory and is supported by past research that has been conducted.

\section{CONCLUSION}

1) Workload significant positive effect on work life balance, 2) Work life balance significantly positive impact on performance, 3) Workload significant negative impact on performance, 4) Workload positive effect performance through work life balance.

\section{SUGGESTION}

For companies the company needs to manage the workload better, so that the workload distribution to all employees. And the need to periodically analyze the workload in the company, thereby knowing the different levels of workload and how to handle the load. The company should pay attention to the level of work life balance of employees, by making programs or policies supporting the work life balance, such as policy making if the employee has done overtime in the evening, then in the day The next employee earns or exchanges the night shift in, as so long as this policy is still not applied. The company is expected to create policies in which the policy can improve more employees' performance there, such as the awarding of bonuses and rewards for employees who are able to perform very well performance.

For further researchers for researchers who want to research workload variables, work life balance, can be developed again. 
Because actual work life balance factors still exist that can be researched, for example about role conflict factor and others. Further researchers should be able to develop or even be able to change with other models so that the research with workload variables, work life balance and performance has other models besides line analysis models like this. Like multiple regression models of workloads and work life balances against performance. Or add intervening variables in addition to work life balance.

\section{REFERENCES}

[1] P.A. Mangkunegara, Manajemen Sumber Daya Manusia Perusahaan. Bandung: Remaja Rosdakaryawa, 2006.

[2] S.R.M. Koesomowidjojo, Panduan Praktis Menyusun Analisis beban kerja. Jakarta: Raih Asa Sukses, 2017.

[3] K.F. Paramitadewi, "Pengaruh Beban Kerja dan Kompensasi Terhadap Kinerja Pegawai Sekretariat Pemerintah Daerah Kabupaten Tabanan," Jurnal Manajemen UNUD, 2017.

[4] L.P. Parkes and P.H. Langford, "Work-life balance or work-life alignment," Journal of Management \& Organization, 2008.
[5] Asima and L. Nilawati, "Pengaruh Work-Life Balance Terhadap Kinerja Karyawan Yang Dimediasi Oleh Komitmen Afektif," Jurnal Ekonomi dan Pembangunan, 2014.

[6] R. Umartiwi, "Hubungan Antara Persepsi Beban Kerja Dengan Work Life Balance Pada Karyawan Bagian Produksi Pt X," Unpublished.

[7] A.L.P. Sari, N. Ardiyanti, and H. Noviardi, "The Impact Of Workload And Role Conflict Towards Work-Life Balance Among Government Auditors In Indonesia," Journal Of Educational Management, 2017.

[8] M. Sarikit, "Pengaruh Work Life Balance Dan Keterikatan Pegawai Terhadap Kinerja Pegawai Fakultas Ilmu Sosial Dan Ilmu Politik Universitas Indonesia," Jurnal Manajemen Pendidikan, 2017.

[9] J. Johari, F.Y. Tan, Fee Y. and Z.I. Tjik, "Autonomy, Workload, Work Life Balance and Job Performance Teachers," Journal of Educational Management, 2016.

[10] R. Asbath, "Pengaruh Beban Kerja Terhadap Kinerja Karyawan Dengan Stres Kerja Sebagai Variabel Intervening Pada PT. Bank Jatim Cabang Bawean," Unpublished.

[11] D. Rizky and T.W. Afrianty, "Pengaruh beban kerja terhadap stres kerja dengan work life balance sebagai variabel intervening (studi pada Dinas Sosial Provinsi Jawa Timur Surabaya)," Journal Ekonomi dan Bisnis, 2018 